\title{
Some Physical and Mechanical Properties of Medium-Density Fiberboard Made from Giant Bamboo
}

\author{
Nelson Potenciano Marinho ${ }^{\mathrm{a}}$,Eduardo Mauro do Nascimento ${ }^{\mathrm{b}}$, \\ Silvana Nisgoski**, Ivaldo de Domenico Valarelli ${ }^{\mathrm{d}}$ \\ ${ }^{a}$ Design Department, Brazil Integrated Faculty - UNIBRASIL, Av. Konrad Adenauer, 442, Tarumã, \\ CEP 82821-020, Curitiba, PR, Brazil \\ ${ }^{\mathrm{b}}$ Mechanical Department, Federal Technological University of Parana - UTFPR, Av. 7 de Setembro, \\ 3165, Rebouças, CEP 80230-901, Curitiba, PR, Brazil \\ 'Forest Technology and Engineering Department, Federal University of Parana - UFPR, \\ Av. Pref. Lothário Meissner, 900, Jardim Botânico, CEP 80210-170, Curitiba, PR, Brazil \\ ${ }^{d}$ Mechanical Department, State University of São Paulo - UNESP, Av. Engenheiro Luiz Edmundo C. Coube, \\ 14-01, CEP 17033-360, Bauru, SP, Brazil
}

Received: November 12, 2012; Revised: June 16, 2013

\begin{abstract}
The objective of this study was to evaluate the density, density profile, water swelling and absorption, modulus of elasticity and rupture from static bending, and tensile strength of experimental medium-density fiberboards manufactured using Dendrocalamus giganteus (Munro bamboo). The fiber production was carried out through the chemo-thermo-mechanical pulping process with four different conditions. The panels were made with $10 \%$ urea formaldehyde resin based on dry weight of the fibers, $2.5 \%$ of a catalyzer (ammonium sulfate) and $2 \%$ paraffin. The results indicate that treatments with the highest alkali $(\mathrm{NaOH})$ percentage, time and splinter heating temperature improved the physical properties of the panels. The root-fiber interface was evaluated through scanning electron microscopy in fracture zones, which revealed fibers with thick, inflexible walls. The panels' mechanical properties were affected due to the fiber wall characteristics and interaction with resin. Giant bamboo fiber has potential for MDF production, but other studies should be carried out.
\end{abstract}

Keywords: Dendrocalamus giganteus, bamboo fiber, MDF panels, physical and mechanical properties

\section{Introduction}

Bamboo is considered to be a promising alternative feedstock in substitution of wood, with several advantages: fast growth and development ${ }^{1}$; high productivity per hectare $^{2}$; low cost management and capital investment ${ }^{3}$; and minimal energy expenses in its processing ${ }^{4}$. Based on these advantages, it is already being used in more than 4,000 different areas ${ }^{5}$.

Originally from Myanmar, Dendrocalamus giganteus Munro is a species of large size ${ }^{6}$ perfectly adapted to the Brazilian climate and soil, which has the highest diversity of species among American countries ${ }^{7}$. However, its use is still incipient due to the lack of technical knowledge in this area ${ }^{8}$.

Several investigations have been carried out to develop different types of panel composites within commercial standards, including OSB panels ${ }^{9,10}$; particleboard panels ${ }^{11-13}$, fiber panels $\mathrm{s}^{14-17}$ and the others mixed with agricultural wastes, such as rice straw $^{18}$. From such investigations, there is a consensus that bamboo has great potential to be used in industrial scale panel manufacture, as long as the technologies involved in such process are updated.

Several pulping processes can be used in the production of MDF panel fibers, such as chemical, physical or purely

*e-mail: silvana.ufpr@gmail.com mechanical ones, besides the combination of some or all of them ${ }^{19}$. In the chemo-thermo-mechanical pulping process, an interrelation occurs between time and heating temperature variables and the minimal quantity of chemical reagents required to rupture the medium lamella, with minimal structural loss of the walls of the fibers without affecting the yield ${ }^{20}$. However, such reagents, e.g., $\mathrm{NaOH}$, contain non-selective hydroxyls that can degrade the hemicelluloses and cellulose, compromising the mechanical properties of the resulting panels. Monitoring such effects is fundamental, since they can result in fiber quality loss, low yield rates and excessive quantities of fines ${ }^{21}$.

Therefore, the aim of this study was to verify the physical-mechanical properties of MDF panels produced with the fibers of Dendrocalamus giganteus bamboo under different pulping conditions.

\section{Material and Methods}

Five-year-old bamboo plants of the Dendrocalamus giganteus species were collected from the Mechanical Engineering Department's bamboo experimentation laboratory within the campus of the University of São Paulo, 
located in Bauru, São Paulo, Brazil. Samples measuring approximately 2 meters in height were extracted from the base and transformed into splinters for the production of fibers through the chemo-thermo-mechanical process. For the sizing, urea formaldehyde Cascamite MDF $8081^{\circledR}$, was used in a $10 \%$ percentage based on anhydrous fiber, $2.5 \%$ of ammonium sulfate as catalyzer and $2 \%$ of paraffin emulsion pulverized in a rotary mixer.

\subsection{Fiber preparation and MDF panel production}

Four types of bamboo fiber panels were produced through the chemo-thermo-mechanical process within three groups of different variables (Table 1). The process began with heat and saturated steam pressure pretreatment using a hydromodule (water) with $1.5 / \mathrm{Kg}$ of bamboo splinters on a dry base.

The heating was performed through a laboratory rotary digester, while the splinter pulping was accomplished with a Bauer type disk shredder working with high mass consistency, namely $40 \mathrm{~L}$ of water at an average temperature of $55^{\circ} \mathrm{C}$ for 15 minutes, with charges of approximately $2 \mathrm{~kg}$ of saturated splinters.

After preparation of the fibers, the material was dried with forced air in a laboratory kiln at a temperature of $70^{\circ} \mathrm{C}$ for 48 hours, reducing moisture levels from $55 \%$ to $6 \%$. The lumps formed during the pulp drying were broken up with a rotating knife mill.

After the application of the resin, the material was manually spread in a lab mold measuring 350 x 350 x $350 \mathrm{~mm}$ (height, width and length) for pre-compression of the fiber bed. The pressing was performed in an automated hydraulic press (PHI brand) with up to 60 tonne capacity, equipped with electrical heating on the plates. The pressing cycle occurred at $150{ }^{\circ} \mathrm{C}$ in four consecutive steps: $40 \mathrm{Kgf} / \mathrm{cm}^{2} / 35 \mathrm{~s}$, $10 \mathrm{Kgf} / \mathrm{cm}^{2} / 90 \mathrm{~s}, 5 \mathrm{Kgf} / \mathrm{cm}^{2} / 90 \mathrm{~s}$ and $3 \mathrm{Kgf} / \mathrm{cm}^{2} / 120 \mathrm{~s}$. The average density of the panels was calculated so as to reach between 0.7 and $0.85 \mathrm{~g} / \mathrm{cm}^{3}$ and the desired thickness about 10 to $12 \mathrm{~mm}$.

\subsection{Determination of the physical-mechanical properties and microanalysis of fractures in MDF panels}

The parameters measured in the panels were density (D), density profile (DP), thickness swelling (TS) and water absorption (WA) for 2 and $24 \mathrm{~h}$. Eight samples of each treatment with dimensions of $50 \times 50 \times 9 \mathrm{~mm}$ (height, length and thickness) were analyzed according to the EN $323^{[22]}$ and EN $317^{[23]}$ standards. The DP measurements

Table 1. Chemo-thermo-mechanical process variables.

\begin{tabular}{cccc}
\hline Treatments & $\begin{array}{c}\text { Heating Time } \\
(\mathbf{m i n})\end{array}$ & $\begin{array}{c}\text { Heating } \\
\text { Temperature } \\
\left({ }^{\circ} \mathbf{C}\right)\end{array}$ & $\begin{array}{c}\text { NaOH } \\
(\%)\end{array}$ \\
\hline T-1 & 20 & 140 & 4 \\
T-2 & 40 & 160 & 4 \\
T-3 & 40 & 160 & 8 \\
T-4 & 60 & 140 & 8 \\
\hline
\end{tabular}

were performed with a DPX300 X-ray density profile analyzer. Eight samples of 230 x 50 x 9 mm for modulus of rupture (MOR) and modulus of elasticity (MOE), and with $50 \times 50 \times 9 \mathrm{~mm}$ for tensile strength (T) were evaluated according to the EN $310^{[24]}$ and EN 319[25] standards. A universal testing machine equipped with a cell with load capacity of 2,000 Kgf ( $20 \mathrm{KN})$ was used in this test.

For the microanalysis of the samples' fracture zones, a Hitachi TM1000 tabletop scanning electron microscope (SEM) was used with direct observation of the material.

\subsection{Statistical procedures}

The means of the treatments were compared through analysis of variance (ANOVA). When differences were detected, Tukey's multiple comparison test was applied ${ }^{26}$. The validity presuppositions regarding normality and homoscedasticity were checked through graphical analysis of the residuals and the Shapiro-Wilks and Bartlett tests ${ }^{27}$. When the presuppositions were not satisfied, the KrukalWallis's nonparametric test was used instead, and in cases of differences between the treatments, nonparametric multiple comparison tests were carried out ${ }^{28}$. The conclusions were based on a significance level of $\alpha=5 \%$ for all tests.

\section{Results and Discussion}

\subsection{Density and density profile}

Density was strongly and significantly associated with the physical and mechanical performance on both thick wood and reconstituted wooden panels. Table 2 presents the means, standard deviations and density profile of the samples measured from surface by X-ray densitometry on bamboo MDF panels produced by different treatments.

By analyzing Table 2 , it can be concluded that the highest density values were found in $\mathrm{T}-1$ and $\mathrm{T}-3$ panels. The lowest value was presented by $\mathrm{T}-4$, which also displayed one of the highest standard deviations, suggesting a sample with a wide variability. In experimental panels, after stabilization (plasticity loss of the fibers) derived from cooling, there is often a slight alteration on thickness due to the tension alleviation, mainly in zones where resin percentage is low. The variability of the samples is also higher deriving from fiber mass dispersion during the pressing process ${ }^{29}$. Dimensional stability can be improved by adding resin to the layers near the outer zone and/or combining different types of $\operatorname{resin}^{30}$.

According to the density profiles obtained by X-ray densitometry curves in all samples (Table 2), the T-3 panels had the best density distribution regularity among the samples, with a mean value of $837 \mathrm{Kg} / \mathrm{m}^{3}$. However, T-1 panel density profile curve's shape resembled that of MDF commercial panels made out of pinus fibers ${ }^{31}$ and experimental panels studied by other authors ${ }^{29,32}$, whose characteristic is higher density at the edges (Figure 1).

\subsection{Thickness swelling (TS) and water absorption (WA) after 2 and $24 \mathrm{~h}$}

Table 3 presents the results obtained from the swelling and water absorption assays in periods of 2 and 24 hours on bamboo MDF panels from all the treatments. 
The results obtained from the tests for water absorption for 2 and $24 \mathrm{~h}$ and swelling for $2 \mathrm{~h}$ were within the stipulated parameters of the EN 317 standard. However, for the swelling after $24 \mathrm{~h}$, only the T-4 panel met the requirements.
By correlating water swelling and absorption in all treatments, it is possible to infer that these properties were adversely influenced and gradually decreased due to heating time and alkali percentage increase. Broadly speaking, the

Table 2. Density and density profile by X-ray densitometry.

\begin{tabular}{cccccccc}
\hline Treatments & \multicolumn{2}{c}{$\begin{array}{c}\text { Density } \\
\left(\mathbf{K g} / \mathbf{m}^{\mathbf{3}}\right)^{*}\end{array}$} & \multicolumn{5}{c}{ Density Profile by X-Ray Densitometry } \\
$\left(\mathbf{K g} / \mathbf{m}^{\mathbf{3}}\right)$
\end{tabular}

*Nonparametric test with a significance level of $0.1 \%$. Mean values followed by identical letters do not statistically differ between each other. SD $=$ Standard Deviation.

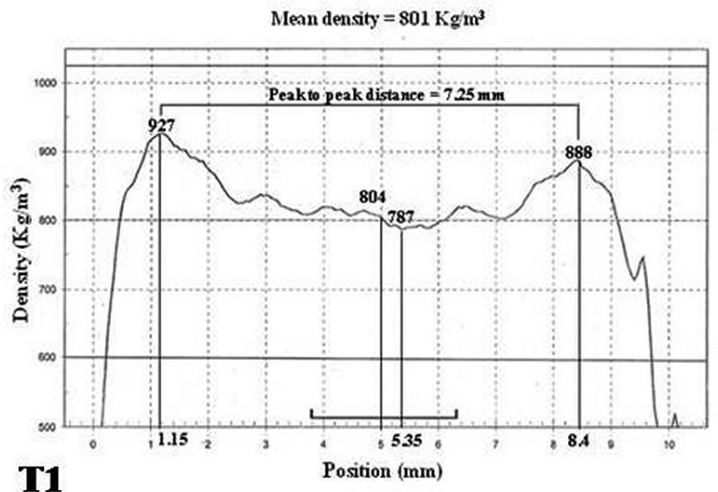

T1

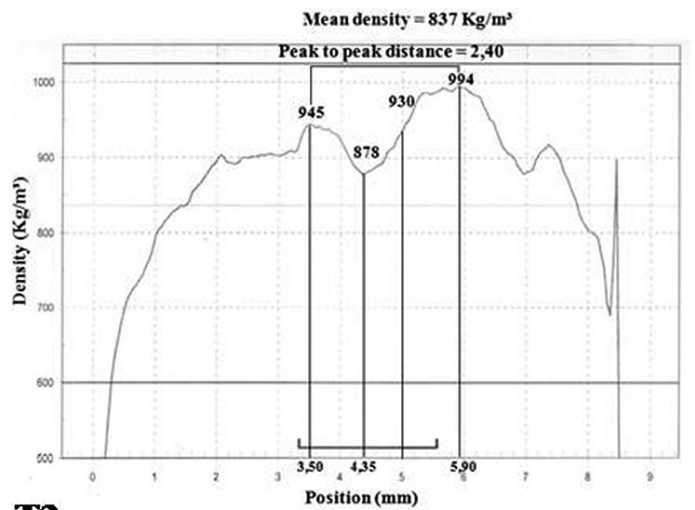

T3
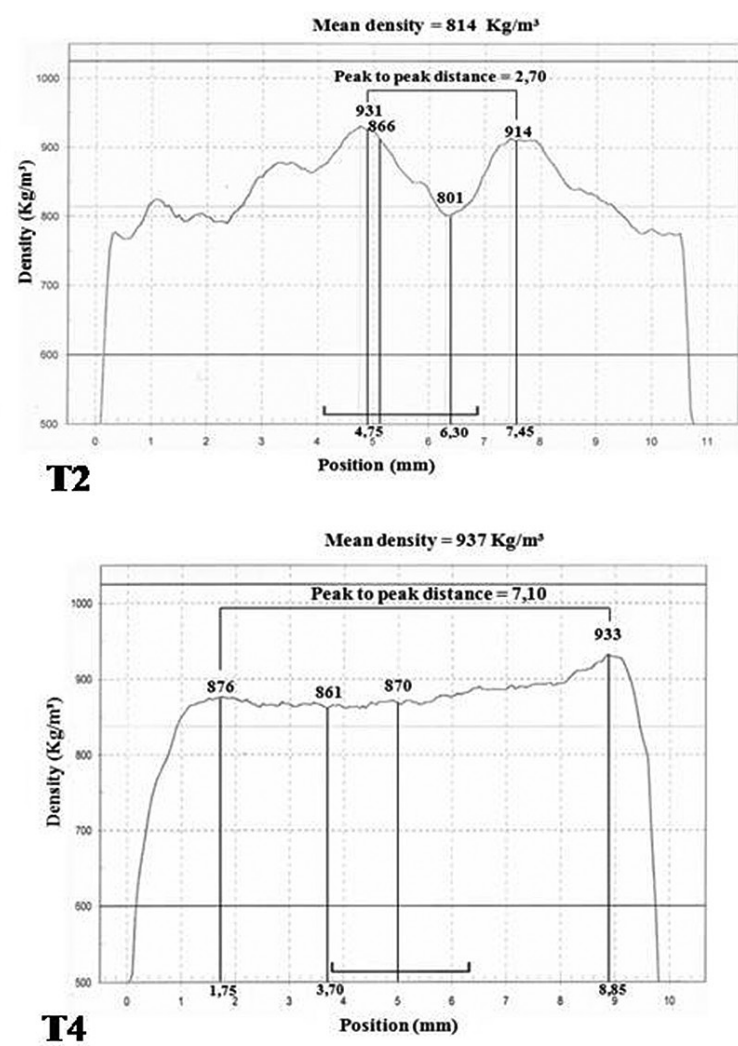

Figure 1. Density profile by X-ray densitometry on the T-1, T-2, T-3 and T-4 panels, respectively.

Table 3. Swelling and water absorption mean values after 2 and $24 \mathrm{~h}$.

\begin{tabular}{ccccccccc}
\hline Treatments & \multicolumn{2}{c}{$\begin{array}{c}\text { Water absorption } \\
(\mathbf{2} \text { hours) }\end{array}$} & \multicolumn{2}{c}{$\begin{array}{c}\text { Water absorption } \\
(\mathbf{2 4} \text { hours) }\end{array}$} & \multicolumn{2}{c}{$\begin{array}{c}\text { Water swelling } \\
(\mathbf{2} \text { hours })^{*}\end{array}$} & $\begin{array}{c}\text { Water swelling } \\
(\mathbf{2 4} \text { hours })^{*}\end{array}$ \\
\hline Mean & SD & Mean & SD & Mean & SD & Mean & SD \\
\hline T-1 & 5.30 & 0.59 & $28.00 \mathbf{a}$ & 2.25 & $4.87 \mathbf{a}$ & 1.12 & $21.74 \mathbf{a}$ & 2.11 \\
T-2 & 5.17 & 0.90 & $23.09 \mathbf{b}$ & 3.19 & $6.53 \mathbf{b}$ & 0.87 & $17.46 \mathbf{b}$ & 1.81 \\
T-3 & 5.05 & 0.77 & $17.14 \mathbf{c}$ & 2.23 & $5.74 \mathbf{a b}$ & 1.44 & $16.09 \mathbf{b}$ & 0.89 \\
T-4 & 4.57 & 0.47 & $14.91 \mathbf{c}$ & 1.57 & $4.96 \mathbf{a}$ & 0.87 & $11.38 \mathbf{c}$ & 1.69 \\
\hline
\end{tabular}

(ns) No statistical difference at a significance level of 5\%. * Nonparametric test with a significance level of 5\%. Mean values followed by identical letters in the columns do not statistically differ. $\mathrm{SD}=$ Standard Deviation. 
extraction of part of the hemicellulose and lignin by more concentrated solutions promote structural changes in the cell walls, affecting both the physical and mechanical properties. UF resin's hydrolysis susceptibility is also a negative trait reflected by weak links ${ }^{33}$.

Furthermore, in the composite panels, water absorption through the fibers produces gradual tumescence of their cell walls, which are basically composed of hemicellulose and cellulose, both of which are hydrophilic components that expand to the point of saturation. From that point on, water molecules begin to occupy the available micro voids, interpenetrating these places and wherever else there is no strong adhesion between the interfaces of the fibers through disruption of these links ${ }^{34}$.

\subsection{Modulus of elasticity (MOE), modulus of rupture (MOR) and tensile strength $(T)$}

Table 4 presents the mean results for MOE and MOR obtained though mechanical tests under static bending and tensile strength resistance.

The MOE, MOR and $\mathrm{T}$ results of all panels did not meet the requirements of the standards. The best result was obtained with the T-3 panel, which is probably due to better interaction between fibers and resin, i.e., more interfacial links between the fibers' walls producing larger contact areas and superior resin anchorage. The quality of these interactions is determined by certain factors, such as the anatomy of the fibers' walls (wall thickness and lumina diameter) and the adequate physical-chemical properties of the resin, which result in better penetration and moistening.

Figure 2 illustrates the panel's rupture zone after static bending tests (A) and the tensile strength of the fibers (B).

The SEM analysis showed fibers that were disordered, with low superficial adhesion. In some cases debonding occurred, as well as the appearance of micro voids, facilitating water penetration. Figure $2 \mathrm{~A}$ shows that after static bending, the wall fibers developed broken heads and wrinkled faces, along with partially broken fibers with microfibils exposed, suggesting low flexibility and interfacial adhesion.

Nevertheless, some factors can directly affect the mechanical properties, such as the resin's nature and the fiber's characteristics ${ }^{35}$. Different results have been obtained through the analysis of different types of coddled fibers with the same type and percentage of resin. The same assay also revealed that different resins produced different results with the same fibers ${ }^{36}$. Such results corroborate that both resins and fibers have individual characteristics that must match during the production of the panels. The alignment of the fibers in industrial manufacture is also another factor that positively affects the mechanical properties of MOE and MOR in MDF panels ${ }^{37}$.

Table 4. Modulus of elasticity and rupture under static bending and tensile strength results.

\begin{tabular}{|c|c|c|c|c|c|c|}
\hline \multirow[t]{2}{*}{ Treatments } & \multicolumn{2}{|c|}{$\begin{array}{c}\text { Modulus of Elasticity } \\
(\mathrm{MPa})^{(\mathrm{ns})}\end{array}$} & \multicolumn{2}{|c|}{$\begin{array}{c}\text { Modulus of Rupture } \\
\left(_{(\mathrm{MPa})^{(\mathrm{ns})}}\right.\end{array}$} & \multicolumn{2}{|c|}{$\begin{array}{l}\text { Tensile Strength } \\
(\mathbf{M P a})^{(*)}\end{array}$} \\
\hline & Mean & SD & Mean & SD & Mean & SD \\
\hline T-1 & $1,249.18$ & 483.04 & 9.38 & 2.44 & $0.10 \mathbf{a}$ & 0.01 \\
\hline T-2 & 877.45 & 139.13 & 8.94 & 0.92 & $0.11 \mathbf{a}$ & 0.03 \\
\hline T-3 & $1,297.51$ & 355.23 & 10.78 & 3.74 & $0.26 \mathbf{b}$ & 0.10 \\
\hline T-4 & $1,067.73$ & 484.72 & 11.10 & 3.92 & $0.10 \mathbf{a}$ & 0.03 \\
\hline
\end{tabular}

(ns) No statistical difference at a significance level of 5\%. (*) $1 \%$ significance level. Mean values followed by identical letters in the columns do not statistically differ. $\mathrm{SD}=$ Standard Deviation.

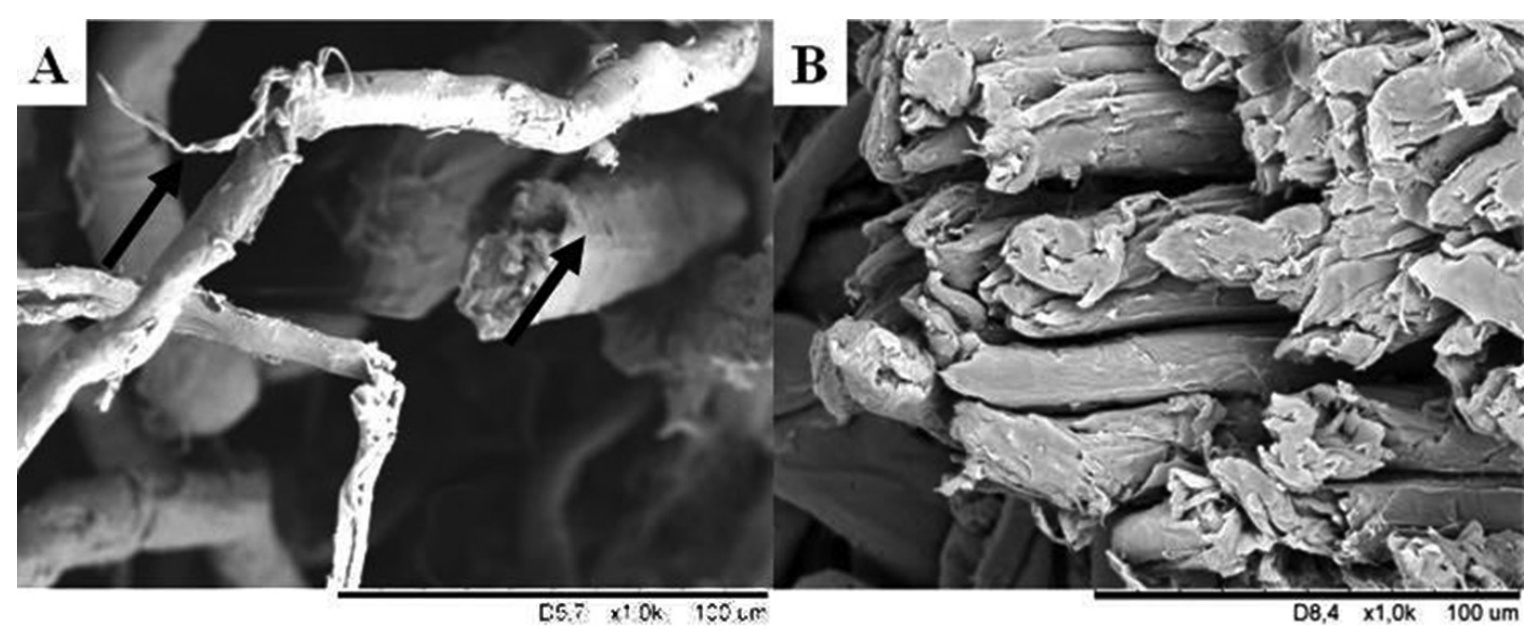

Figure 2. T-3 panel SEM. Rupture zone after static bending tests (A) and tensile strength of the fibers (B). 


\section{Conclusion}

- Higher mean density rates and homogeneity in their profile positively affect the mechanical properties;

- The results obtained from water absorption for 2 and $24 \mathrm{~h}$ were within the stipulated parameters of the EN 317 standard;

- Longer heating time and increased alkali levels caused a significant and gradual decrease in water absorption and swelling after $24 \mathrm{~h}$;

\section{References}

1. Kigomo B. Guidelines for growing bamboo. Nairobi: Kenya Forestry Research Institute; 2007.

2. Pereira MAR and Garbino LV. Desenvolvimento e produção do bambu gigante (Dendrocalamus giganteus) cultivado na Unesp/Campus de Bauru - SP., com vistas à sua utilização na engenharia agrícola. In: Anais do XXXII Congresso Brasileiro de Engenharia Agrícola; 2003; Goiânia. Goiânia; 2003.

3. Reubens R. Bamboo in sustainable contemporary design. Beijing: International Network for Bamboo and Rattan (INBAR); 2010. Working Paper 60.

4. Higuchi T. Bamboo in Japan. In: Proceeding of the XVII World Congress - International Union of Forestry Research Organization; 1981; Japan. Japan: Kyoto University, 1981.

5. Hsiung W. Prospects for bamboo development in the world. Journal of American Bamboo Society. 1991; 8(1-2):168-178.

6. Montiel M and Sánchez E. Ultraestrutura de bambúes del gênero Dendrocalamus (Poaceae: Bambusoideae) cultivados em Costa Rica III: Dendrocalamus giganteus. Revista de Biologia Tropical. 2006; 54(Suppl.2):59-63.

7. Filgueira TS and Gonçalves AP. A checklist of basal grasses and bamboos in Brazil (Poaceae). Journal of American Bamboo Society. 2004; 18(1):7-18.

8. Beraldo AL and Azzini A. Bambu: características e aplicações. Guaíba: Editora Guaíba; 2004.

9. Febrianto F, Sahroni, Hidayat W, Bakar ES, Kwon GJ, Kwon $\mathrm{JH}$ et al. Properties of oriented strand board made from Betung bamboo (Dendrocalamus asper (Schultes.F) Backer ex Heyne). Wood Science and Technology. 2012; 46(1-3):53-62. http:// dx.doi.org/10.1007/s00226-010-0385-8

10. Malanit P. The suitability of Dendrocalamus asper Backer for oriented strand lumber. [Thesis]. Hamburg: University of Hamburg; 2009.

11. Ahmad M. Analysis of Calcutta bamboo for structural composite materials. [Dissertation]. Virginia: Virginia Polytechnic Institute and State University; 2000.

12. Sukuno T and Han KS. Manufacture and properties of board made from fresh Mosochiku bamboo. In: Proceeding of the international conference on forest products; 2003; Daejeon, Korea. Daejeon; 2003. p. 325-330.

13. Bai X. Experimental and numerical evaluations of structural bamboo-based composite materials. [Dissertation]. Clemson: Clemson University; 1996.

14. Li XB. Physical, chemical and mechanical properties of bamboo and its utilization potential for fiberboard manufacturing. [Thesis]. Louisiana: Louisiana State University; 2004.

15. Xu Y, Zhan Y and Wang W. Study on manufacturing technology of MDF from bamboo. In: Proceeding of the utilization of agricultural and forestry residues; 2001; Nanjing. Nanjing; 2001. p. 117-123.
- The microanalysis carried out through the SEM observations of fracture zones revealed inflexible, misaligned fibers, indicating little interfacial adhesion, which can result in weak contact areas and insufficient adhesive anchorage, ultimately leading to inferior mechanical performance;

- Giant bamboo fiber has potential for MDF production, but studies with another resin should be carried out.

16. Matsumoto K, Yamaguchi H and Yoshida H. Manufacture and properties of board made from moso bamboo. Mokusai Gakkaishi. 2001; 47(2):111-119.

17. Marinho NP. Características das fibras do bambu (Dendrocalamus giganteus) e potencial de aplicação em painéis de fibras de média densidade (MDF). [Dissertação]. Curitiba: Universidade Tecnológica Federal do Paraná; 2012.

18. Bauchongkol P, Hiziroglu S, Fueangvivat V, Jarusombuti S and Soontonbura W. (2009) Bamboo (Dendrocalamus asper) as raw material for interior composite panel manufacture in Thailand. In: Proceeding VIII World Bamboo Congress Thailand: Bamboo, the Environment and Climate Charge; 2003; Bangkok, Thailand. Bangkok; 2003, v. 2, p. 24-34.

19. Kokta BV and Ahmed A. Feasibility of explosion pulping of bagasse. Cellulose Chemistry and Technology. 1992; 26:107-123.

20. Ramos LP. The chemistry involved in the steam treatment of lignocellulosic materials. Química Nova. 2003; 26(6):863-871. http://dx.doi.org/10.1590/S0100-40422003000600015

21. Foelkel CEB. O processo de impregnação dos cavacos de madeira de eucalipto pelo licor Kraft de cozimento. In: Eucalyptus Online Book \& Newletter. ABTCP; 2009. cap 15.

22. European Committee for Stardardization. European Standard EN 323: Wood based panels - determination of density. Brussels; 1993.

23. European Committee for Standardization. European Standard EN 317: Particleboards and Fiberboards - Determination of swelling in thickness after immersion in water. Brussels; 1993.

24. European Committee for Standardization. European Standard EN 310: Wood-based panels - determination of modulus of elasticity in bending and of bending strength (B). Brussels; 1993.

25. European Committee for Standardization. European Standard EN 319: Particleboards and Fiberboards - determination of tensile strength perpendicular to the plane of the board. Brussels; 1993.

26. Pimentel-Gomes F. Curso de Estatística Experimental. 14th ed. Piracicaba: Escola Superior de Agricultura Luiz de Queiroz; 2001.

27. Montgomery DC. Design and analysis of experiments. 5th ed. John Willey and Songs, 2001.

28. Campos H. Estatística experimental não-paramétrica. 14th ed. Piracicaba: Escola Superior de Agricultura Luiz de Queiroz; 1983.

29. Eleotério JR. Propriedades físicas e mecânicas de painéis $M D F$ de diferentes densidades e teores de resina. [Dissertação]. Piracicaba: Universidade de São Paulo; 2000.

30. Myers GC. Relationship of fiber preparation and characteristics to performance of medium-density hardboards. Forest Products Journal. 1983; 33(10):43-51. 
31. Torquato LP. Caracterização dos painéis MDF comerciais produzidos no Brasil. [Dissertação]. Curitiba: Universidade Federal do Paraná; 2008.

32. Ferreira ES. Propriedades físico-mecânicas de painéis de fibras de média densidade (MDF) produzidos com resinas convencionais e modificadas com tanino de acácia negra. [Tese]. Curitiba: Universidade Federal do Paraná; 2010.

33. Conner AH. Urea formaldehyde adhesive resin. In: Polymeric Materials Encyclopedia. Boca Raton: CRC Press; 1996. v. 11, p. 8496-8501.

34. Tita SPS, Paiva JMF and Frollini E. Resistência ao impacto e outras propriedades de compósitos lignocelulósicos: matrizes termofixas fenólicas reforçadas com fibras de bagaço de cana de açúcar. Polímeros. 2002; 12(4):228-239. http://dx.doi. org/10.1590/S0104-14282002000400005

35. Chow $\mathrm{P}$ and Zhao L. Medium density fiberboard made from phenol resin and wood residues of mixed species. Forest Products Journal. 1992; 42(10):65-67.

36. Campos CI. Produção e caracterização físico-mecânica de MDF a partir de fibras de madeira de reflorestamento $e$ adesivos alternativos em diferentes teores. [Tese]. São Carlos: Universidade de São Paulo; 2005.

37. Niemz P and Poblete H. Investigations on the dimensional stability of MDF and particleboards. Holz als Roh- und Werkstoff. 1996; 54(2):141-144. http://dx.doi.org/10.1007/ s001070050154 